\title{
Hector Berlioz's "Te Deum"
}

Author(s): J. S. Shedlock

Source: The Musical Times and Singing Class Circular, Vol. 25, No. 502 (Dec. 1, 1884), pp.

684-686

Published by: Musical Times Publications Ltd.

Stable URL: http://www.jstor.org/stable/3356039

Accessed: 27-06-2016 09:44 UTC

\footnotetext{
Your use of the JSTOR archive indicates your acceptance of the Terms \& Conditions of Use, available at

http://about.jstor.org/terms
}

JSTOR is a not-for-profit service that helps scholars, researchers, and students discover, use, and build upon a wide range of content in a trusted digital archive. We use information technology and tools to increase productivity and facilitate new forms of scholarship. For more information about JSTOR, please contact support@jstor.org.

\footnotetext{
Musical Times Publications Ltd. is collaborating with JSTOR to digitize, preserve and extend access to The Musical Times and Singing Class Circular
} 
second time, to inform myself of the new sort of music which had been developed there since my first journey, and which was now in use. The new music was doubtless the composition of Monteverde. In August, I63I, the father of Schïtz died, and he returned to Dresden, where he stayed but a short time, and afterward journeyed to the principal towns in Italy. In I634 he again passed through Germany, still suffering from the plague of war, and eventually settled for four years at Copenhagen, where he was received with much distinction; he left Denmark in 1638 and went to Brunswick and Lunebourg, returning to Copenhagen in 1642 . He received the appointment of Chapel-master to the king, but the happy restoration of peace to Germany enabled him to go back to Dresden, where he spent the remainder of his days. Becoming afflicted with deafness he devoted himself to the study of the Scriptures, and the composition of sacred music, producing numerous Psalms and Motetts, and four settings of "The Passion." Two years before his death, at his request, his pupil, Bernhard, director of music at Hamburg, composed a funeral chant for five voices, in the style of Palestrina, for performance at his funeral. Schütz died on November 6, I672, in the 88th year of his age, having been Chapel-master to the Elector of Saxony fifty-seven years. Much of his church music was planned for performance by a double choir, and was largely coloured by orchestration for stringed and wind instruments. It is remarkable for its true expression of the sentiment of the text, for rhythm and sweetness of cadence. A list of the compositions by Schüt $z$ would be lengthy, and must be reserved for a future occasion; but mention may be made of his Opera "Daphné," composed to a libretto translated by Opitz from Rinuccini, remarkable as being the first German opera. His most beautiful composition is said to be an Oratorio on "The Passion," preserved in manuscript in the Royal Library at Dresden. Schütz added the grace of the Italian manner to the strength of the German school, and was the first to give due place to solo and chorus in musical illustrations of Bible narrative. Unfortunately for us, so far as I know, the music of Schütz is not easily obtained, with the exception of some very beautiful extracts from his "Passion Music," introduced to public notice by Herr Pauer in 1873 , and published by Novello, Ewer and Co. These are to be had, and I recommend them to the notice of my readers in the hope that their beauty and excellence will induce some London Musical Society to take them into consideration, with a view to a fitting performance in 1885 to celebrate the centenary of Heinrich Schütz, justly called by his contemporaries "The Father of German Music."

\section{HECTOR BERLIOZ'S "TE DEUM."}

By J. S. SHedLOCK, B.A.

THis extraordinary work, which Mr. A. Manns intends shortly to produce at the Crystal Palace, was first performed at the church of St. Eustache, Paris, on April 30, I855, under the composer's direction. When the work has been heard the musical critics will tell us what they think of it; meanwhile, we propose to give a brief description of the various movements, hoping to interest those who are unacquainted with the score. The work is usually spoken of as one for two choirs, orchestra and organ, although in reality there are three: a first choir of sopranos, tenors and basses; a second choir similarly composed, and a third of children's voices. This children's choir, in performance, ought to be separated from the other two choirs, and placed on a raised platform not far from the orchestra. But the composer, in a note prefixed to the full score, intimates that this third choir may be dispensed with, although he adds that "il contribue puissament à l'effet." In three out of the six sections of the work it is not even employed, and when used it doubles (with few and comparatively unimportant exceptions) the other voices either in unison or in the octave. For his orchestra Berlioz demands 25 first violins, 24 second, I 8 violas, I 8 cellos, and I 6 double-basses-in all Ior strings. Of wood wind : 4 flutes, 4 oboes, 4 clarinets, an English horn, bass clarinet, and 4 bassoons. Of brass : 4 horns, 2 trumpets, 2 cornets, 6 tenor trombones, I ophicleide, and I tuba. Also kettledrums, drums, gross-caisse, and cymbals; and besides, the organ.

For his first choir he requires too voices (40 sopranos, 30 tenors, and 30 basses), the same for his second, and for the third 6oo, or, as he naively says in a note, " aussi nombreux que possible."

The first movement opens with a succession of chords for orchestra and organ alternately. The organ then gives out a bold theme, which is afterwards combined with the principal subject led off by the sopranos. To save space we give these two melodies together, as they occur after the one marked $a$ has been treated in fugal style:-

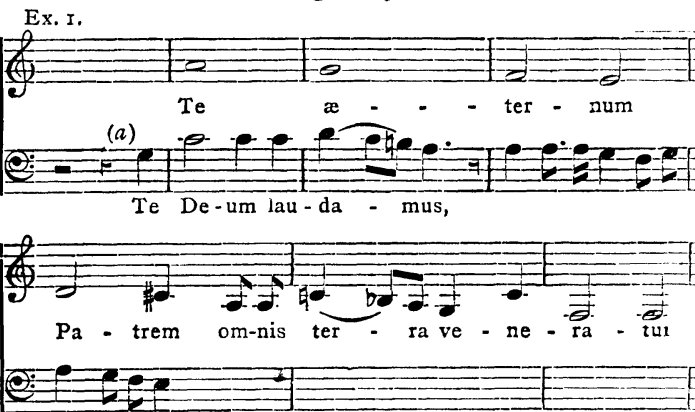

The movement might really be described as an irregular double fugue on two subjects, or we might even say three, if we include a counter-subject which plays rather an important part in the opening. A clear knowledge and remembrance of the two themes quoted will enable the listener to understand the main scope and design of the whole movement. The one marked $a$ forms in one place the material for an able stretto while part of the other in another place is employed near the close with a strange progression of chords. Berlioz cleverly avoids consecutive fifths and octaves in the instrumental parts, but they are perceptible to the ear if not to the eye-

Ex. 2.

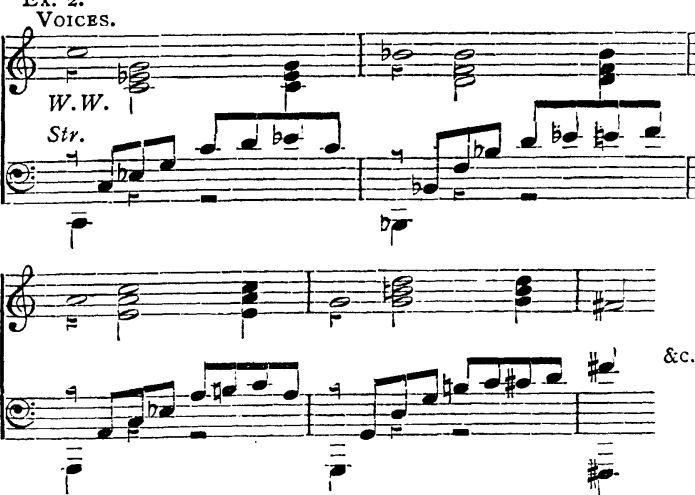

The piece opens in $\mathrm{F}$ major but closes on the chord of $\mathrm{F}$ sharp as dominant of $\mathrm{B}$ major, the key of the following movement-i.e., "Tibi omnes." Here at first 
only female voices are employed, supported by wood wind without bassoons, horns, and strings, with sparing use of double-basses. The organ opens with a quiet symphony of sixteen bars, and it also plays a few bars between the vocal phrases. At the words "Plœni sunt cœli" the three choirs combine, and at the words " gloriæ tuæ" the full force of the orchestra is heard for the first time. The vibrating cymbals will here attract attention. The opening phrase, repeated so many times during the course of the piece, with slight variations according to the different words, is as follows-

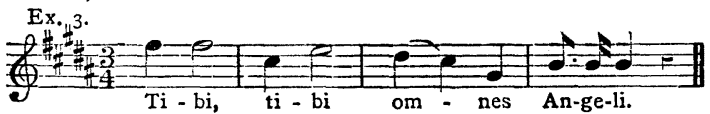

It is allotted to men's voices after we have passed from heaven to earth, from Cherubim and Seraphim to Apostles, Prophets, and Martyrs. This second section winds up like the first with the forte "tuæ gloriæ." The phrase (Ex. 3) is then taken up by bass voices in the key of E, the subdominant, followed by a vigorous forte passage, and the movement concludes with a repetition of the opening symphony, this time allotted to strings, wood wind, and cornets. We cannot now describe the beautiful, quaint, and simple effects of harmony, and the delicacy of the orchestration. The composer, as we have seen, has at his command a huge array of forces, but the various instruments are used singly or in small groups to give variety of tone-colour; it is only once or twice they all unite for a burst of sound. And to one other feature of this movement we would call attention. Example 3 is repeated a number of times, but each time accompanied in a different manner. The reiterated phrase gives unity to the whole piece; the surroundings, variety. The third movement is the prayer "Dignare Domine;" there are no trombones, tuba, or drums used. A short symphony for organ, with pizzicato chords for strings, leads to the entry of the voicessopranos of first choir and the basses of the two choirs. Over a long violoncello pedal (D) the sopranos enter singing-

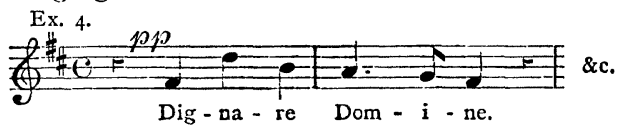

At the fifth bar the basses come in with "Domine," thus-

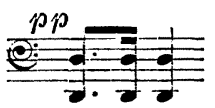

and immediately afterwards the tenors answer with the theme. Soon the music modulates to the key of $\mathrm{F}$ major, and there is a long pedal $\mathrm{F}$ also assigned to the celli; from $F$ we get to $A$, and from $A$ to $c$; from there we proceed to $\mathrm{e}$ flat, and by enharmonic modulation to e natural. As the violoncellos ascended, so in like manner do they descend: from e to c sharp, then to A, F, and finally to D, when the movement closes. Over this curious bass the voice parts-i.e., sopranos and tenors, move about in rather a vague manner; the bass voices follow the violoncello notes, sometimes singing exactly with them, sometimes muttering several words in monotone fashion over one long note. Twice in the course of the movement first basses sing fifth above. To give proper effect to this number the bass voices must be deep and full-toned; the pedal notes indicated above show what they have to sing, and here is their part just at the end-

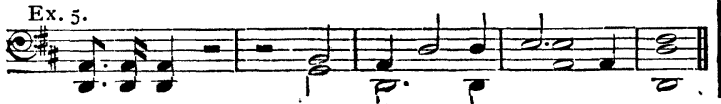

The double-basses are not used after the opening prelude, and the organ comes in only in one or two places; the violins and violas for the most part support the voices, while the wood-wind instruments move about in an independent and often original manner,

In the next number, "Christe Rex gloriæ," neither trombones nor organ are used. The key is again $\mathrm{D}$ major. The voices enter at once with a phrase commencing-

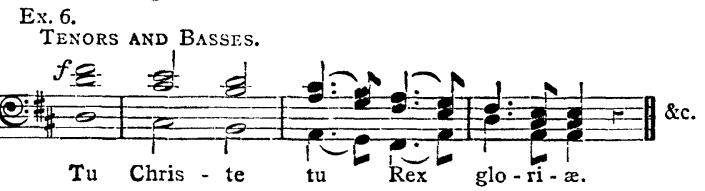

After this theme has been repeated with four-part and different harmony, we come to the following-

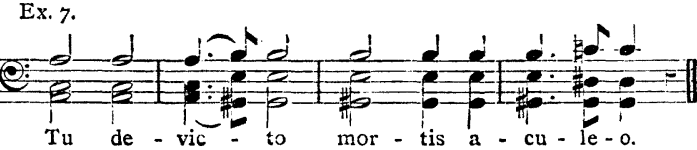

These two quotations will enable us to follow the first section of the movement. Example 6 is treated in stretto fashion, the voices coming in at the interval of a second below; Examples 6 and 7 are worked together. A sudden and Beethovenish transition from the key of $\mathrm{D}$ to that of $\mathrm{F}$ occurs near the close of this section.

When we come to the words "Ad liberandum," \&c., the tenors of the first choir take up a plaintive theme; violins and violas strike piano pizzicato chords, the wood wind and first horn move along quietly with detached chords or short legato phrases, only the violoncellos supporting this slender fabric of sound. In one passage the violas divide, accompanying the vocal part in unison and octave. At the words "Tu ad dexteram" the orchestration becomes pretty full; the wood wind sustains the voices; and to these the pizzicato quaver figure of strings and longsustained notes for horns, with occasional roll of the drum, must produce a striking contrast. We now return to the opening theme, this time set to the words "Sedes ad dexteram Dei." The passage begins forte; then we have a long crescendo passage, and after some effective writing for the voices they come to a close with the usual cadence, while the orchestra winds up with a few bars in which the principal theme is again heard. No. 5 is the prayer "Te Ergo Quæsumus." The key is $\mathrm{G}$ minor. The English horn and bass clarinet is used, and also the trombones, but there is no organ. Throughout this short movement the orchestration is very varied and, so far as we can judge, very effective. The principal theme is first heard in the opening symphony and then taken up by a tenor soloEx. 8.

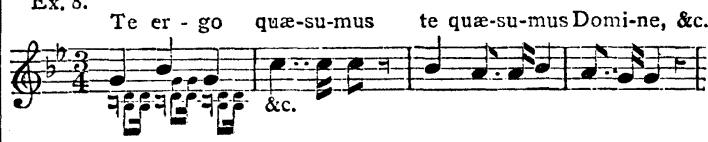

This theme is accompanied by strings, with an agitated figure indicated in first bar of Ex. 8. After a time sopranos of both choirs sing in monotone "Fiat super nos misericordia tua Domine," accompanied, piano, by cornets and trombones. The tenor solo is followed a second time by a similar passage. The key now changes to $\mathrm{G}$ major. In the soft ending we notice first a triplet phrase-

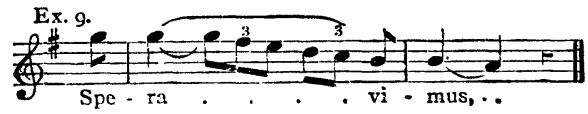


which has already cast its shadow before it in the first part of the movement, then the delicate accompaniment of wood wind, and lastly, the principal theme (Ex. 8) in major, harmonised for unaccompanied voices with melody in bass. When they cease, two pizzicato chords for strings bring the movement to an end, and well does this quiet end contrast with the loud and harsh organ tones heard at the opening of the next piece. Of the sixth and concluding number of the work, Berlioz, in his Mémoires, says :- "Le finale (Judex crederis) est sans aucun doute ce que j'ai produit de plus grandiose." And in a letter to his son Louis, dated April 27, 1855 (only a few days before the performance), he writes:"Yesterday we had our first rehearsal at St. Eustache, with the orchestra and 600 children. It is beginning to progress. It is colossal! There is a finale which, I verily believe, is grander than the Tuba mirum of my Requiem." As yet, however, we can neither endorse nor contradict the composer's opinions.

The organ opens with a theme which plays throughout the movement a very prominent part. We give it as first heard from the basses of the first choir-

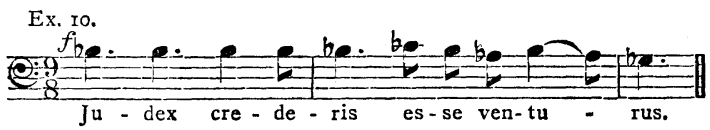

Let us call it the $\mathcal{f} u d g m e n t$ theme. The key is $\mathrm{E}$ flat minor, but by means of an enharmonic modulation the sopranos come in on B as dominant of $\mathrm{E}$ minor; the tenors take up the theme still a semitone higher, on the C. The other voices of the two choirs gradually enter; we hear the cry of hope ("In te Domine speravi"), and the imploration ("Non confundar in xternum"). Strange modulations, weird harmonies produced by passing notes, mutterings of the violoncellos and double-basses, long sustained notes of the trombones and ophicleide forcing their way through the body of voices supported by strings and wood wind, and the inexorable Judgment theme-all attract notice in the long drawn-out sentence which closes with a diminuendo on the chord of $\mathrm{B}$ flat minor.

Hitherto, it may be remarked, the movement has had no key signature. It commenced, as we have said, in $\mathrm{E}$ flat minor. Berlioz now having made up his mind to remain for a time in one key, or its relative major, puts a signature of five flats. The sopranos of both choirs then begin thus-

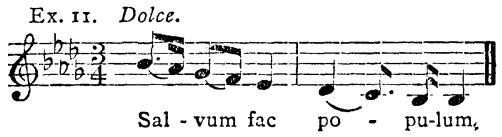

the phrase, or portion of one, consisting of the notes of the descending scale of $\mathrm{B}$ flat minor. The music continues for a time in melodious though rather mournful strains. The orchestral accompaniment contains no brass, and is principally occupied in supporting the voices. A modulation is soon made to $\mathrm{D}$ flat, the relative major, and the basses sing a phrase remarkable for its diatonic and tuneful character-

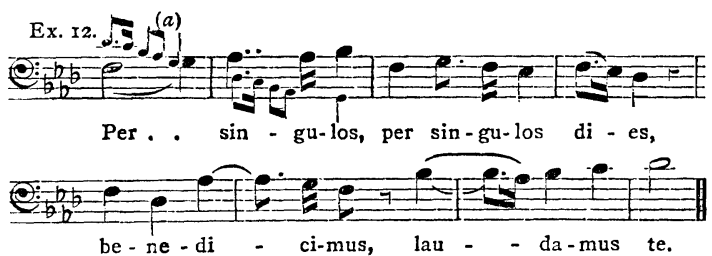

The key-note heard at the beginning of each barspeaks of the praise repeated "per singulos dies," while the phrase from Ex. II points to the hopes of the worshippers (see Ex. I2,a) during this act of praise. This phrase (Ex. II) is now sung in the major key (D flat) to the words "per singulos dies," and when the "laudamus te" follows, the ominous sounds of the Judgment theme are uttered by the bass voices, supported by horns and double-basses pizzicato; the strings continue with the phrase of which Ex. II gives the commencement. This combination of themes is extremely interesting, and we are sorry that want of space forbids further quotation.

We must, indeed, hurry on. The sounds of coming judgment fill the air-

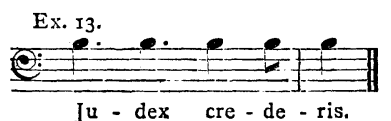

is repeated again and again, haunting one like the Nibelungen rhythm in Wagner's trilogy. The sustained notes mentioned above increase in intensity. In vain in loud and piercing tones the voices cry "In te Domine speravi," the violins give out the phrase associated with the prayer "Bless thy heritage," but the dreadful sounds are heard through everything. Soon the organ supports the bass instruments; the voices sing in unison and octave, and four drums (sans timbre) give the rhythm of the Judgment theme. An enharmonic modulation leads us from $E$ flat minor to $\mathrm{E}$ minor; the time changes from 9-8 to $3-4$. Most effective in one place is the wild burst of the voices with the "heritage" phrase to the words "non confundar"; and this same phrase is given out in soft tones by strings without double-basses after the singers have ended with a diminucndo "in aternam." Towards the close of the movement the key changes to $\mathrm{B}$ flat major. The music reminds us of the middle section in $\mathrm{D}$ flat; there is the perpetual striking of the tonic and the reiteration of the "Salvum" theme; but the voices are singing "Non confundar in æternam," and terrible sounds are heard from the orchestra. The day of judgment seems to have come. Berlio $z$ now puts forth his whole strength: the shouting of the voices, the blare of the brass, including ophicleide and tuba, the piercing notes of the flutes and clarinets, the Judgment theme in diminished form furiously played by the violins-such are the sounds with which the piece hatens to a close. However, four bars before the end, the milder tones of the "heritage" theme are heard throwing, as it were, a gleam of light and hope over the dire scene; then come two bars fortissimo with the tonic chord, and all is over. In the full score a movement follows, entitled "Marche pour la présentation des Drapeaux"; but it has really nothing to do with the Te Deum. Although not a military occasion, the March was, however, played at St. Eustache. For its performance, in addition to a big orchestra, twelve harps are needed.

\section{REMINISCENCE OF CATALANI.}

Although a man may have reached the extremest limits of old age he has still one enjoyment left, the intellectual power of realising the scenes of his early. youth, and even of enacting them over again, sometimes in their minutest details, a power which clings to his brain even when his physical faculties have all deserted him. This magic influence was roused within my own mind on reading, in the French papers of the I $5^{\text {th }}$ of September, the account of the marriage of Mdlle. Deslandes, the great-granddaughter of Madame Catalani! The announcement brought to memory my own last souvenir of the great singer, and the visit I paid her on her 